\title{
EFFECT OF (HALEX-2) BIOFERTILIZER INOCULATION ON COWPEA YIELD AND MINERAL FERTILIZER-N OPTIMIZATION
}

Atia, R. H. *; H. S. Hamoud* ; A.S.M. El-Saady* and M. H. Kasem**

* Soils, Water and Environment Res. Inst. ARC, Giza, Egypt

${ }^{* *}$ Veg. Res. Dept., Hort. Res. Inst. ARC, Giza, Egypt

\begin{abstract}
A field experiment was conduced during the summer seasons of 2005 and 2006 at Disuq district, Kafr El-Sheikh Governorate to study the combined effect of inoculation with Halex-2 (as biofertilizer) and mineral nitrogen levels on cowpea yield and their net return.

Split plot design was used with four replicates. The main plots were assigned by two treatments of uninoculated (control), and inoculated with Halex-2. Whereas, the sub-plots were assigned by five $\mathrm{N}$ levels $\left(0,10,20,30\right.$ and $40 \mathrm{~kg} \mathrm{~N}$ fed $\left.^{-1}\right)$.

Four polynomial quadratic equations were established to show the following results:

1. The maximum and optimum $\mathrm{N}$ rates were decreased as Halex-2 used in the two seasons.

2. The maximum and optimum cowpea yields were increased as Halex-2 used in the two seasons.

3. The highest maximum yield $\left(1413.2 \mathrm{~kg} \mathrm{fed}^{-1}\right)$, the highest total value of yield $\left(7065.0\right.$ L.E fed $^{-1}$ ) and the highest return of bio and N fertilizer (2936.6 LE fed ${ }^{-1}$ ) were obtained as Halex-2 used in the first season.

4. The average of efficiency and the efficiency of nitrogen fertilizer at optimum rate were increased as Halex-2 used.

5. The soil nitrogen content during plant growth $\left(X_{s}\right)$ was increased as Halex-2 added.

6. The contribution of soil $\mathrm{N}$ was increased as Halex-2 used in the two seasons.

7. The contribution of $\mathrm{N}$ fertilizer was increased as $\mathrm{N}$ levels increased in the two seasons.

Keywords: Biofertilizer inoculation-cowpea the quadratic polynomial equationnitrogen levels.
\end{abstract}

\section{INTRODUCTION}

Recently, great efforts are expanded to increase the legumes production in Egypt. Legumes production can help in solving the problem of fodder shortage as it is considered one of the most important sources of protein for human and their livestock. Cowpea (Vigna unquiculata L. Walp) is one of the most important vegetable legumes due to its high protein content, heat tolerant, low fertilizer requirements and it can grow easily in the new reclaimed lands (EI-Waraky and Kasem, 2007).

In the semi-arid regions, soil is inherently poor in nitrogen due to fast degradation of organic matter. Thus, nitrogen fertilization is usually required. Cowpea, like other legumes, have a symbiotic relationship with a specific soil bacteria (Rhizobium spp.), which fixes atmospheric nitrogen. However, under low available nitrogen in the soil starter of nitrogen fertilizer is required before 
the fixation begins, either from the soil reserve or through $\mathrm{N}$ application (Hussaini et al., 2004). Since $\mathrm{N}_{2}$-fixation usually initiated after nodule formation. Thus mineral N, especially nitrate (Fathy et al., 2000) or/and biological fertilization (Hassanein and El-Shebiny, 2000) may be a critical source of nitrogen for legume plants. Several investigators (Hassouna and Abou-Nasr, 1992 on soybean; Hassanein and El-Shebiny, 2000 on sugar beet and Bin Ishaq, 2002 on pea) indicated that application of biofertilizer Halex-2 at $10 \mathrm{~g} . \mathrm{kg}^{-1}$ seeds significantly resulted in taller plants with more $\mathrm{N}$ concentrations in leaves, higher protein contents in seeds, and greater total yields than in the case of untreated control.

The excessive use of nitrogen fertilizers represents the major cost of crop production and creates pollution of agroecosystem (Fisher and Richter, 1984). Therefore many investigators have given more attention to the quantitative expression of the response of crops to fertilizer application based on changes in cultural practices. Thabet and Balba (1994), Hassanein and ElShebiny (2000), Atia (2005) and Atia et al. (2007) were used the polynomial quadratic equations to calculate the net return from optimum rates of nitrogen applied and the contribution of soil and fertilizer nutrients to the yield.

The objective of the present study is to estimate the more economic use of bio and mineral fertilizers and determine the returns from optimum rates of nitrogen applied to cowpea.

\section{MATERIALS AND METHODS}

A field experiment was carried out at Disuq district Kafr El-Sheikh Governorate, during the summer seasons of 2005 and 2006 using cowpea (Vigna unquiculata L. Walp) seeds variety Kafr El-Sheikh-1. The physical and chemical soil properties of the experimental sites were determined according to Jackson (1958) and presented in Table 1.

Table 1: Some properties of the experimental soils.

\begin{tabular}{|c|c|c|c|c|c|c|c|c|c|c|}
\hline \multirow[b]{2}{*}{ Season } & \multicolumn{3}{|c|}{ Mechanical analysis } & \multirow[b]{2}{*}{ Texture } & \multirow{2}{*}{$\mathrm{pH}^{\star}$} & \multirow{2}{*}{$\begin{array}{l}E C^{* *} \\
\mathrm{dSm}^{-1}\end{array}$} & \multirow{2}{*}{$\underset{\%}{\text { O.M. }}$} & \multicolumn{3}{|c|}{$\begin{array}{c}\text { Available elements } \\
\text { ppm }\end{array}$} \\
\hline & $\begin{array}{c}\text { Sand } \\
\%\end{array}$ & $\begin{array}{c}\text { Silt } \\
\%\end{array}$ & $\begin{array}{c}\text { Clay } \\
\%\end{array}$ & & & & & $\mathbf{N}$ & $\mathbf{P}$ & $\mathrm{K}$ \\
\hline $1^{\text {st }}$ & 9 & 51 & 40 & & 7. & 1.2 & 1.67 & 2 & 5. & 440 \\
\hline $2^{\text {nd }}$ & 8.7 & 52 & 39.3 & Loamy clay & 7.9 & 1.1 & 1.70 & 22 & 5.5 & 380 \\
\hline
\end{tabular}

*1: 25 soil: water suspension

** Soil paste extract

Halex-2; is a biofertilizer containing a mixture of non symbiotic $\mathrm{N}_{2}$ fixing bacteria of the general Azospirillum, Azotobacter and Klebsilla, was used. The biofertilizer was supplied by the biofertilization Unit. Plant Pathology Department, Alex. Univ. The biofertilizer was used at the rate of 10 g. $\mathrm{kg}^{-1}$ seeds. Seed inoculation was performed by adding an adequate amount of distilled water to the biofertilizer and mixed with the seeds just before sowing. Uninoculated seeds (control treatment) were mixed with distilled water. In all treatments cowpea seeds were inoculated by an 
effective strain of rhizobium bacteria just before sowing. The sowing dates were 15 and 18 of April in the first and second seasons, respectively.

Split-plot design was used with four replicates. The main plots were assigned by two treatments (uninoculated and inoculated with Halex-2), whereas the sub-plots were assigned by five $N$ levels $(0,10,20,30$ and $40 \mathrm{~kg}$ $\left.\mathrm{N} / \mathrm{fed}^{-1}\right)$. Each sub-plot contained 4 rows, $4 \mathrm{~m}$ in long and $0.6 \mathrm{~m}$ in width, comprising an area of $9.6 \mathrm{~m}^{2}$. Spacing between plans within rows was $20 \mathrm{~cm}$ and sowing was done on one side of the row. Plants were thinned to two plants per hill after three weeks from the planting. Nitrogen fertilizer, in the form of ammonium sulphate $(20.5 \% \mathrm{~N})$, was added to the soil as one dose before the first irrigation. The other recommend agriculture practices were used.

After harvest seed yields were determined. All obtained data were statically analyzed using COSTAT Software (1985).

Quantitative analysis:

The quadratic polynomial equation has been used to describe the cowpea seed yield response to nitrogen levels and biofertilizer (Halex-2), its general form is:

$$
Y=B_{0}+B_{1} X_{i} \pm B_{2} X^{2}
$$

Where, the term, $(Y)$ is the yield corresponding to nutrient rates $X_{i}$. The term $B_{0}$ is the intercept, and $B_{1}$ and $B_{2}$ are the linear and quadratic coefficients, respectively. The constraints $B_{0}, B_{1}$ and $B_{2}$ were calculated using the least squares method.

The maximum addition of fertilizer $\left(\mathrm{X}_{\mathrm{m}}\right)$, the maximum yield $\left(\mathrm{Y}_{\mathrm{m}}\right)$, the optimum rate of fertilizer $\left(\mathrm{X}_{\mathrm{opt}}\right)$, the optimum yield $\left(\mathrm{Y}_{\mathrm{opt}}\right)$, the average of efficiency $(e \bar{X})$ of the fertilizer application rate $(x)$ along the range from $x=0$ to $x=i$, the efficiency of fertilizer at optimum rate (exopt), the efficiency of soil nitrogen $\left(e x_{s}\right)$ and the soil nitrogen content $\left(\mathrm{x}_{\mathrm{s}}\right)$ can be calculated from the following equations, respectively.

1. $\mathrm{X}_{\mathrm{m}}=-\frac{\mathrm{B}_{1}}{2 \mathrm{~B}_{2}}$

Balba (1961)

2. $\mathrm{Y}_{\mathrm{m}}=\mathrm{B}_{0}-\frac{\mathrm{B}_{1}^{2}}{4 \mathrm{~B}_{2}}$

Capurro and Voss (1981)

3. $\mathrm{X}_{\mathrm{opt}}=\frac{\mathrm{P}_{\mathrm{r}}-\mathrm{B}_{1}}{2 \mathrm{~B}_{2}}$

Balba (1964)

4. $\mathrm{Y}_{\mathrm{opt}}=\mathrm{B}_{0}+\frac{\mathrm{Pr}^{2}-\mathrm{B}_{1}^{2}}{4 \mathrm{~B}_{2}}$

Balba (1964)

Where the $(\mathrm{Pr})=\frac{\text { Price of fertilizer unit }}{\text { Price of one } \mathrm{kg} \text { of crop }}$

5. $e \bar{X}=B_{1}+B_{2} X_{i} \ldots$ at $X_{i}=5$ units

Thabet and Balba (1994). 
Atia, R. H. et al.

6. $\mathrm{eX}_{\mathrm{opt}}=\mathrm{B}_{1}+\mathrm{B}_{2} \mathrm{X}_{\mathrm{opt}} \ldots$ at $\mathrm{X}=$ optimum rate

Hassanein and El-Shebiny (2000)

7. $\quad \mathrm{eX}=\frac{\mathrm{B}_{0}}{\mathrm{X}_{\mathrm{s}}}$

Thabet and Balba (1994)

8. $\mathrm{X}_{\mathrm{s}}=\frac{-\mathrm{B} \pm \sqrt{\mathrm{B}_{1}^{2}-4 \mathrm{~B}_{0} \mathrm{~B}_{2}}}{2 \mathrm{~B}_{2}}$ at $\mathrm{y}=0$

9. $S E=\sqrt{\frac{(\text { Observed }- \text { Calcualted })^{2}}{n-2}}$

10. The contribution of soil $\mathrm{N}=\frac{\mathrm{X}_{\mathrm{S}}}{\mathrm{X}_{\mathrm{f}}+\mathrm{X}_{\mathrm{S}}} \times$ calculated yield

11. The contribution of fertilizer $=\frac{X_{f}}{X_{f}+X_{S}} \times$ calculated yield

\section{RESULTS AND DISCUSSION}

In the present study, cowpea seed yields were increased successively and significantly with $\mathrm{N}$ increments. The polynomial quadratic equations were established to express the cowpea seeds response to $\mathrm{N}$ application with or without the biofertilizer (Halex-2) are presented in Table 2.

Table 2: The polynomial equations expressing yield of cowpea seedrates of nitrogen with and without the biofertilizer (Halex-2) in the two seasons (2005-2006).

\begin{tabular}{|c|c|l|c|}
\hline Season & Treatment & \multicolumn{1}{|c|}{ The polynomial equations } & $\mathbf{X}_{\mathbf{s}}$ \\
\hline \multirow{2}{*}{2005} & $\mathrm{~N}$ & $\mathrm{Y}=711.23+351.68 \mathrm{X}-52.807 \mathrm{X}^{2}$ & 1.63 \\
\cline { 2 - 4 } & $\mathrm{N}+$ Halex & $\mathrm{Y}=825.68+357.71 \mathrm{X}-54.450 \mathrm{X}^{2}$ & 1.81 \\
\hline \multirow{2}{*}{2006} & $\mathrm{~N}$ & $\mathrm{Y}=643.31+358.95 \mathrm{X}-51.557 \mathrm{X}^{2}$ & 1.48 \\
\cline { 2 - 4 } & $\mathrm{N}+\mathrm{Halex}$ & $\mathrm{Y}=789.40+332.92 \mathrm{X}-48.49 \mathrm{X}^{2}$ & 1.86 \\
\hline \multirow{2}{*}{ Average } & $\mathrm{N}$ & $\mathrm{Y}=677.27+355.31 \mathrm{X}-52.182 \mathrm{X}^{2}$ & 1.55 \\
\cline { 2 - 4 } & $\mathrm{N}+$ Halex & $\mathrm{Y}=807.54+345.32 \mathrm{X}-51.46 \mathrm{X}^{2}$ & 1.84 \\
\hline
\end{tabular}

The experimental and calculated cowpea seed yields values obtained from the polynomial equations 1-6 are presented in Table 3 . The calculated yields closely approximate experimental yield as shown form the values of standard error (SE) of estimates and determination coefficient $\left(R^{2}\right)$. The chi square test showed that the calculated yield values from each equations do not significantly differ from the experimental values for each treatment (Table 3). 
Table 3: Observed and calculated cowpea seed yield $\mathrm{kg}_{\text {fed. }} \mathrm{-}^{-1}$ under levels of nitrogen fertilizer and addition of biofertilizer (Halex2) in the two seasons (2005 and 2006).

\begin{tabular}{|c|c|c|c|c|c|c|c|}
\hline \multirow{2}{*}{ Inoculation } & \multirow{2}{*}{ N levels } & \multicolumn{2}{|c|}{ Season 2005 } & \multicolumn{2}{c|}{ Season 2006 } & \multicolumn{2}{c|}{$\begin{array}{c}\text { Average of } \\
\text { 2005 and 2006 }\end{array}$} \\
\cline { 3 - 9 } & & Observe & Calculate & Observe & Calculate & Observe & Calculate \\
\hline \multirow{5}{*}{ Without } & 0 & 708.30 & 711.23 & 654.00 & 643.31 & 681.15 & 677.27 \\
& 10 & 1022.20 & 1010.10 & 931.30 & 950.70 & 976.75 & 980.40 \\
& 20 & 1184.60 & 1203.35 & 1149.00 & 1154.97 & 1166.80 & 1179.16 \\
& 30 & 1303.90 & 1291.00 & 1283.50 & 1256.14 & 1293.70 & 1273.57 \\
& 40 & 1269.70 & 1273.03 & 1241.50 & 1254.19 & 1255.60 & 1263.61 \\
\hline \multirow{4}{*}{ With } & 0 & 819.90 & 825.68 & 797.90 & 789.40 & 808.90 & 807.54 \\
inoculation & 10 & 1152.50 & 1128.94 & 1063.50 & 1073.85 & 1108.00 & 1101.39 \\
& 20 & 1287.30 & 1323.30 & 1241.40 & 1261.34 & 1264.35 & 1292.32 \\
& 30 & 1433.20 & 1408.76 & 1388.80 & 1351.87 & 1411.00 & 1380.31 \\
& 40 & 1379.10 & 1385.32 & 1330.30 & 1345.44 & 1354.70 & 1365.38 \\
\hline
\end{tabular}

\section{Maximum and optimum rates:}

The values of maximum and optimum $\mathrm{N}$ rates for each treatment were calculated and presented in Table 4 . The maximum $N$ rates $\left(X_{m}\right)$ decreased from 3.33 unit $\mathrm{N}$ fed ${ }^{-1}$ to 3.28 unit $\mathrm{N}_{\text {fed }}{ }^{-1}$ and from 3.48 unit $\mathrm{N}$ fed ${ }^{-1}$ to 3.43 unit $\mathrm{N} \mathrm{fed}^{-1}$ as biofertilizer Halex-2 added in the first and second seasons, respectively. The mean values of the two seasons decreased from 3.40 unit $\mathrm{N}$ fed ${ }^{-1}$ to 3.36 unit $\mathrm{N}$ fed ${ }^{-1}$ as biofertilizer Halex-2 was used. The values of the optimum $\mathrm{N}$ rates $\left(\mathrm{X}_{\mathrm{opt}}\right)$ show the same trend, where it decreased as biofertilizer Halex-2 was used in the first and second seasons. On the other hand, the values of $X_{\text {opt }}$ were less than the values of $X_{m}$, whereas the $X_{o p t}$ were calculated by differentiating $(y)$ in the polynomial equations from 1-6 with regard to $X(\mathrm{dy} / \mathrm{dx})$ and equating with the ratio $(\mathrm{Pr})$ of the price of fertilizer unit and the price of cowpea unit $(\mathrm{kg})$. The decrease of $X_{m}$ and $X_{\text {opt }}$ as biofertilizer Halex-2 added may be attributed to two reasons. The first is the effect of non symbiotic $\mathrm{N}_{2}$-fixing bacteria on soil nitrogen, where the soil nitrogen increased from 1.63 unit $\mathrm{N}$ fed ${ }^{-1}$ to 1.81 unit $^{N}$ fed ${ }^{-1}$ and from 1.48 unit $\mathrm{N}_{\text {fed }}^{-1}$ to 1.86 unit $\mathrm{N} \mathrm{fed}^{-1}$ in the first and second seasons, respectively (Table 2). The second is the increase of the surface area per unit root length and enhanced root hair branching with an eventual increase in the uptake of nutrients from the soil (Jagnow et al., 1991). The results are in agreement with those obtained by Shiboob (2000) and Hassanein and ElShebiny (2000).

\section{The maximum and optimum yield:}

Data tabulated in Table 4 show that the maximum and optimum cowpea yields were increased as Halex-2 used. The $Y_{m}$ increased from $1296.8 \mathrm{~kg} \mathrm{fed}^{-1}$ to $1413.2 \mathrm{~kg} \mathrm{fed}^{-1}$ and from $1268.1 \mathrm{~kg} \mathrm{fed}^{-1}$ to $1361.0 \mathrm{~kg} \mathrm{fed}^{-1}$ as Halex-2 used in the first and second seasons, respectively. The average of the increase in the two seasons was $8.2 \%$ 
Table 4: The maximum $N$ rate $\left(X_{m}\right)$, optimum $N$ rate $\left(X_{\text {opt }}\right)$, maximum yield $\left(Y_{m}\right)$, optimum yield $\left(X_{o p t}\right)$ and the returns of cowpea under (Halex-2) biofertilizer inoculation and mineral fertilizerN.

\begin{tabular}{|c|c|c|c|c|c|c|c|c|c|c|c|c|c|}
\hline Season & Treat. & 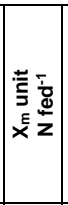 & 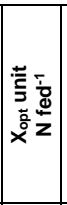 & 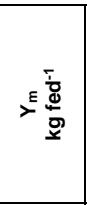 & 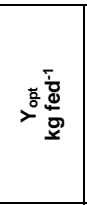 & 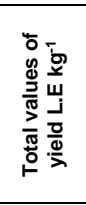 &  & 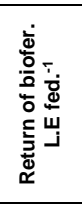 & 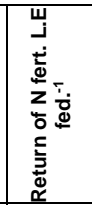 & 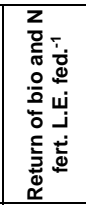 & 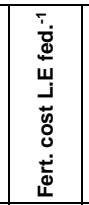 & 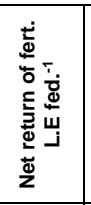 & L.E./L.E. \\
\hline \multirow{2}{*}{2005} & $\mathrm{~N}$ & 3.33 & 3.26 & 1296.8 & 1296.5 & 6482.5 & 3556.2 & - & 2926.4 & 2926.4 & 110.8 & 2815.0 & 25.41 \\
\hline & $\mathrm{N}+\mathrm{H}$ & 3.28 & 3.22 & 1413.2 & 1413.0 & 7065.0 & 4128.4 & 572.2 & 2364.4 & 2936.6 & 129.5 & 2807.1 & 21.68 \\
\hline \multirow{2}{*}{2006} & $\mathrm{~N}$ & 3.48 & 3.41 & 1268.1 & 1267.8 & 6339.0 & 3216.5 & - & 3122.5 & 3122.5 & 116.0 & 3006.5 & 25.92 \\
\hline & $\mathrm{N}+\mathrm{H}$ & 3.43 & 3.36 & 1361.0 & 1360.7 & 6803.5 & 3947.0 & 730.5 & 2126.0 & 2856.5 & 134.2 & 2722.3 & 20.29 \\
\hline \multirow{2}{*}{ Average } & $\mathrm{N}$ & 3.40 & 3.34 & 1282.1 & 1281.9 & 6409.5 & 3386.4 & - & 3023.1 & 3023.1 & 113.6 & 2909.5 & 25.61 \\
\hline & $\mathrm{N}+\mathrm{H}$ & 3.36 & 3.29 & 1386.9 & 1389.6 & 6933.0 & \begin{tabular}{|l|}
4037.7 \\
\end{tabular} & 651.3 & 2244.0 & 2895.3 & 131.9 & 2763.4 & 20.95 \\
\hline \multicolumn{3}{|c|}{$\begin{array}{l}\text { Price of cowpea } \\
\text { Fertilizer price } \\
\text { Halex Price } \\
\text { Fertilizer unit } 10\end{array}$} & $\begin{array}{l}=5 \mathrm{~L} \\
=34 \\
=20\end{array}$ & $\begin{array}{l}\text {.E. kg } \\
\text { L.E un }\end{array}$ & & & & & & & & & \\
\hline
\end{tabular}

\section{The returns from applied optimum rates:}

The returns per feddan from the applied nitrogen (optimum rates) with and without Halex-2 inoculation were presented in Table 4. The results show that the total values of yield increased from $6582.5 \mathrm{~L}^{-\mathrm{E}}$ fed $^{-1}$ to 7065.0 L.E fed ${ }^{-1}$ and from 6339.0 L.E. fed ${ }^{-1}$ to 6803.5 L.E. fed ${ }^{-1}$ in the first and second season, respectively. Also, the total values of the control was yield at control increased as Halex-2 added to soil in the two seasons. The average of the two seasons was increased from 3386.4 L.E fed ${ }^{-1}$ to $4037.7 \mathrm{~L}^{2} \mathrm{E}$ fed $^{-1}$ as Halex-2 used. This result means that addition of one unit of Halex-2, (its price was 20 L.E.) gave us an increase of yield equal to 651.3 L.E. fed ${ }^{-1}$. On contrast the return of nitrogen fertilizer decreased as Halex-2 added to soil, where the average of the two seasons decreased from 3023.1 L.E. fed ${ }^{-1}$ to $2244.0 \mathrm{~L}^{\mathrm{E}} \mathrm{fed}^{-1}$. Again the net return of fertilizer decreased from $2815.6 \mathrm{LE}$ fed $^{-1}$ to 2807.1 L.E. fed $^{-1}$ and from 3006.5 L.E. fed $^{-1}$ to 2722.3 L.E. fed $^{-1}$ in the first and second seasons, respectively. Also, the L.E/L.E decreased from 25.61 L.E/L.E to 20.95 L.E/L.E. as Halex-2 used in the two seasons. Generally, the addition of Halex-2 increased the total values of yield, the total values of yield at control and save money and fertilizer.

\section{Efficiencies of nitrogen fertilizer and soil nitrogen:}

The efficacies of soil nitrogen $\left(e X_{s}\right)$, the average efficiency $(e \bar{X})$ and the efficiency of nitrogen fertilizer at optimum rate $\left(\mathrm{e} \mathrm{X}_{\mathrm{opt}}\right)$ are present in Table 5. The data illustrate the effect of Halex-2, where the eX increased from $436.34 \mathrm{~kg} \mathrm{unit}^{-1} \mathrm{fed}^{-1}$ to $456.18 \mathrm{~kg} \mathrm{unit}^{-1} \mathrm{fed}^{-1}$ in the first season, but it decreased in the second one. The average of the two seasons increased from 436.95 to $438.88 \mathrm{~kg} \mathrm{unit}^{-1} \mathrm{fed}^{-1}$. The increase of soil nitrogen efficiency means that the nitrogen introduced by $\mathrm{N}_{2}$-fixing bacteria was available to cowpea plants. Also, the average efficiency and the efficiency of nitrogen fertilizer at optimum rate increased as Halex-2 added to soil in the two seasons (Table 5). 
Table 5: Efficiencies of soil nitrogen $\left(e X_{s}\right)$, the average efficiency $(e \bar{X})$ and the efficiency of nitrogen fertilizer at optimum rate $\left(\mathrm{eX}_{\mathrm{opt}}\right)$ and the soil nitrogen $\left(X_{s}\right)$.

\begin{tabular}{|c|c|c|c|c|c|}
\hline \multirow{2}{*}{ Season } & \multirow{2}{*}{ Treatment } & $\begin{array}{c}\left(\mathbf{X}_{\mathbf{s}}\right) \text { unit N } \\
\text { fed. }\end{array}$ & eX & eX & EXopt \\
\cline { 3 - 6 } & & & \multicolumn{3}{|c|}{ Kg unit $^{-1}$ fed $^{-1}$} \\
\hline \multirow{2}{*}{2005} & $\mathrm{~N}$ & 1.63 & 436.34 & 500.00 & 539.08 \\
& $\mathrm{~N}+\mathrm{H}$ & 1.81 & 456.18 & 607.88 & 650.35 \\
\hline \multirow{2}{*}{2006} & $\mathrm{~N}$ & 1.48 & 434.67 & 437.08 & 467.50 \\
& $\mathrm{~N}+\mathrm{H}$ & 1.86 & 424.41 & 595.48 & 626.51 \\
\hline \multirow{2}{*}{ Average } & $\mathrm{N}$ & 1.55 & 436.95 & 468.54 & 502.98 \\
& $\mathrm{~N}+\mathrm{H}$ & 1.84 & 438.88 & 601.70 & 638.24 \\
\hline
\end{tabular}

\section{Contribution of soil and fertilizer N:}

The results in Table 6 show that the contribution of $\mathrm{N}$ fertilizer were increased as $\mathrm{N}$ rates increased from $\mathrm{N}_{0}$ up to $\mathrm{N}_{4}$ in the two seasons. Generally, the contribution fraction of soil $\mathrm{N}$ were decreased as $\mathrm{N}$ rates increased in the two seasons (Table 7). The contribution fraction of soil nitrogen was higher as Halex added than it without addition of biofertilizer. Data in Tables 6 and 7 show three trends. The first is the contribution of soil $\mathrm{N}$ increased as Halex added to cowpea plants in the two seasons. The second is the contribution fraction and the contribution of soil $\mathrm{N}$ was decreased as $\mathrm{N}$ rates increased. The third one is the contribution fraction and the contribution of fertilizer $\mathrm{N}$ take the negative trend compared with the soil $\mathrm{N}$. This may be due to the fixed-N by the non symbiotic $\mathrm{N}_{2}$-fixing bacteria in the biofertilizer (Halex-2), which increased soil-N. Thus it decreased the fertilizer contribution.

Table 6: The contribution of soil $\mathbf{N}$ and added $\mathrm{N}$ fertilizer to cowpea yield in the two seasons (2005 and 2006).

\begin{tabular}{|c|c|c|c|c|c|c|c|}
\hline \multirow{2}{*}{ Inoculation } & \multirow{2}{*}{ N-level } & \multicolumn{2}{|c|}{2005} & \multicolumn{2}{c|}{2006} & \multicolumn{2}{c|}{$\begin{array}{c}\text { Average of } \\
\text { 2005 and 2006 }\end{array}$} \\
\cline { 3 - 8 } & & Soil N & Fert. N & Soil N & Fert. N & Soil N & Fert. N \\
\hline \multirow{5}{*}{ Without } & $\mathrm{N}_{0}$ & 711.23 & 0.00 & 643.31 & 0.00 & 677.27 & 0.00 \\
inoculation & $\mathrm{N}_{1}$ & 626.26 & 383.84 & 570.42 & 380.28 & 598.04 & 382.36 \\
& $\mathrm{~N}_{2}$ & 541.51 & 661.84 & 496.64 & 658.33 & 518.83 & 660.33 \\
& $\mathrm{~N}_{3}$ & 450.85 & 839.15 & 414.53 & 841.61 & 433.01 & 240.56 \\
& $\mathrm{~N}_{4}$ & 369.18 & 903.82 & 338.63 & 915.56 & 353.81 & 909.80 \\
\cline { 2 - 8 } & $\mathrm{N}_{\mathrm{opt}}$ & 427.85 & 868.65 & 380.34 & 887.46 & 410.21 & 871.69 \\
\hline \multirow{5}{*}{ With } & $\mathrm{N}_{0}$ & 825.68 & 0.00 & 789.4 & 0.00 & 807.54 & 0.00 \\
& $\mathrm{~N}_{1}$ & 722.52 & 406.42 & 698.0 & 375.85 & 715.90 & 385.49 \\
& $\mathrm{~N}_{2}$ & 635.18 & 688.12 & 605.44 & 655.90 & 620.31 & 672.01 \\
& $\mathrm{~N}_{3}$ & 535.33 & 873.43 & 513.71 & 838.16 & 524.52 & 855.79 \\
& $\mathrm{~N}_{4}$ & 429.44 & 955.88 & 430.54 & 914.90 & 436.92 & 928.46 \\
\cline { 2 - 8 } & $\mathrm{N}_{\mathrm{opt}}$ & 508.68 & 904.32 & 489.85 & 870.85 & 499.18 & 887.42 \\
\hline
\end{tabular}


Atia, R. H. et al.

Table 7: The contribution fraction of soil $\mathbf{N}$ and added $\mathbf{N}$ fertilizer to cowpea plants at two seasons (2005 and 2006).

\begin{tabular}{|c|c|c|c|c|c|c|c|}
\hline \multirow{3}{*}{ Inoculation } & \multirow{2}{*}{ N-level } & \multicolumn{2}{|c|}{2005} & \multicolumn{2}{c|}{ 2006 } & \multicolumn{2}{c|}{$\begin{array}{c}\text { Average of } \\
\text { 2005 and 2006 }\end{array}$} \\
\cline { 2 - 7 } & & Soil N & Fert. N & Soil N & Fert. N & Soil N & Fert. N \\
\hline \multirow{5}{*}{ Without } & $\mathrm{N}_{0}$ & 1.00 & 0.00 & 1.00 & 0.00 & 1.00 & 0.00 \\
inoculation & $\mathrm{N}_{1}$ & 0.62 & 0.38 & 0.60 & 0.40 & 0.61 & 0.39 \\
& $\mathrm{~N}_{2}$ & 0.45 & 0.55 & 0.43 & 0.57 & 0.44 & 0.56 \\
& $\mathrm{~N}_{3}$ & 0.35 & 0.65 & 0.33 & 0.67 & 0.34 & 0.66 \\
& $\mathrm{~N}_{4}$ & 0.29 & 0.71 & 0.27 & 0.73 & 0.28 & 0.72 \\
\cline { 2 - 8 } & $\mathrm{N}_{\mathrm{opt}}$ & 0.33 & 0.67 & 0.30 & 0.70 & 0.32 & 0.68 \\
\hline \multirow{5}{*}{ With } & $\mathrm{N}_{0}$ & 1.00 & 0.00 & 1.00 & 0.00 & 1.00 & 0.00 \\
& $\mathrm{~N}_{1}$ & 0.64 & 0.36 & 0.65 & 0.35 & 0.65 & 0.35 \\
& $\mathrm{~N}_{2}$ & 0.48 & 0.52 & 0.48 & 0.52 & 0.48 & 0.52 \\
& $\mathrm{~N}_{3}$ & 0.38 & 0.62 & 0.38 & 0.62 & 0.38 & 0.62 \\
& $\mathrm{~N}_{4}$ & 0.31 & 0.69 & 0.32 & 0.68 & 0.32 & 0.68 \\
\cline { 2 - 8 } & $\mathrm{N}_{\mathrm{opt}}$ & 0.36 & 0.64 & 0.36 & 0.64 & 0.36 & 0.64 \\
\hline
\end{tabular}

\section{REFERENCES}

Atia, R.H. (2005). A quantitative evaluation of soybean response to nitrogen under sulphur and phosphorus addition. Alex. Sci. Exch. Journal, 26(4): 355-362.

Atia, R.H.; R.E. Knany; A.S. M. El-Saady and M.I. Zidan (2007). Sugar beet response to nitrogen forms and rates under different tillage practices expressed by polynomial quadratic equations Egypt. J. Agric. Res. 85(4): 1127-1139.

Balba, M.A. (1961). Quantitative soil-plant relationship through mathematical and radioactive technique. Alex. J. Agric. Sci., 11: 1098. p: 109.

Balba, M.A. (1964). A quantitative study of cotton response to nitrogen and phosphorus fertilization. J. Soil Sci. U.A.R., 4. (2): 105-117.

Bin Ishaq, M.S. (2002). comparisons among the effects of biofertilizer, nitrogen and boron on growth, seed production and seed quality of peas (Pisum sativum L.). Ph.D. Thesis, Fac. Agric., Alex. Univ., Egypt.

Capurro, E. and R. Voss (1981). An index of nutrient efficiency and its application to corn yield response application. Agron. J., 73: 128-135.

COSTAT (1985). User's Manual. Verson 3, Cohort, Tuson, Arizona, U.S.A.

El-Waraky, Y.B. and M.H. Kasem (2007). Effect of biofertilization and nitrogen levels on cowpea growth, production and seed quality. J. Agric. Res. Kafr El-Sheikh Univ., 33(2), 434-447.

Fathy, T. Mikhaeel, Ahmed M. Shalaby and Mona M. Hanna (2000). Dinitrogen and nitrogen assimilation as influenced by dual (VaMycorrhizal Fungi-Rhizobium) inoculation in soybean plants. Annals Agric Sci. Ain Shams Univ. 45(1): 67-77.

Fisher, A. and C. Richter (1984). Influence of organic and mineral fertilizers on yield and quality of potatoes. Proc. The Fifth IFOAM International Scientific Conference, Univ. of Kassel, Germany, p. 37.

Hassanein, M.A. and G.M. El-Shebiny (2000). Contribution of bio- and mineral nitrogen fertilization in sugar beet yield. Alex. Sci. Exch., 21(2): 129-143. 
Hassouna, M.G. and A. Abou-Nasr (1992). Application of growth promoting rhizobacteria and vesicular arbuscular mycorrhiza on soybean (Glycine max) on the poor lands of N.W. Egypt. Com. In Sci. and Dev. Res. 39: 47-61.

Hussaini, M.A.; M.I. Othman; M.F. Ishyaku and A.M. Falaki (2004). Response of cowpea to methods and levels of nitrogen application under varying fertilizer levels in a semi-arid regions of Nigeria, J. of Food, Agric. \& Environment. 2(3 \& 4): 137-140.

Jackson, M.L. (1958). Soil Chemical Analysis. Nitrogen of determination for soils and plant tissue

Jagnow, G.; G. Hoflich and K.H. Hofmann (1991). Inoculation of nonsymbiotic rhizosphere bacteria, possibilities of increasing and stabilizing yields. Angew. Botanki. 65: 97-126 (C.F. Hort. Abst. 44(2): 433, 1993).

Shiboob, R.M. (2000). Effects of nitrogen fertilizer levels and biofertilizer types on growth, yield and quality of common bean (Phaseolus vulgaris L.). M.Sc. Thesis, Faculty of Agric., Alex. Univ. Egypt.

Thabet, A.G. and A.M. Balba (1994). Soil and fertilizer-N efficiencies using wheat grain response equations to $\mathrm{N}$ and tillage. Arid Soil Research and Rehabilitations 8: 115-124.



